\title{
Investigation of Isotherm, Kinetics and Thermodynamics of Ciprofloxacin Adsorption by Molecularly Imprinted Polymer from Aqueous Solutions
}

\author{
Maryam Bazi ${ }^{1}$, Davoud Balarak ${ }^{2}$, Aram Dokht Khatibi ${ }^{2}$, Shaziya Haseeb Siddiqui ${ }^{3}$, Ferdos Kord Mostafapour ${ }^{2, *}$ \\ 'Student Research Committee, Zahedan University of Medical Sciences, Zahedan, IRAN. \\ 2Department of Environmental Health Engineering, Health Promotion Research Center, Zahedan University of Medical Sciences, Zahedan, IRAN. \\ ${ }^{3}$ Department of Chemistry, Sam Higginbottom University of Agriculture Technology and Sciences (SHUATS), Allahabad, Uttar Pradesh, INDIA.
}

\begin{abstract}
Background: Improper use of antibiotics and their discharge into the environment have serious and dangerous consequences. About 30-30\% of antibiotics are not metabolized in the body and enter the environment through urine and feces, so the main source of antibiotics in the environment is wastewater treatment plant effluent. The aim of this study was to investigate the removal efficiency of ciprofloxacin (CIP) from aqueous media by molecularly imprinted polymer (MIP). Methods: This study is an experimental-laboratory study performed in a reactor with a discontinuous system. In this study, the effect of parameters such as solution $\mathrm{pH}$, adsorbent dose, initial concentration of $\mathrm{CIP}$, reaction contact time and reaction temperature on the reduction rate the antibiotics amoxicillin and CIP were administered. Results: Results showed that removal efficiency for both antibiotics was increased with increasing contact time and adsorbent mass and initial antibiotics concentration while decreased with increasing solution $\mathrm{pH}$ and the best $\mathrm{pH}$ to remove was neutral $\mathrm{pH}$. Equilibrium data were analyzed by Freundlich and Langmuir isotherm models and the results showed that the data from Langmuir isotherm
\end{abstract}

had a higher correlation coefficient. In addition, the reaction rate was performed with pseudo-first-order and pseudo-second-order models, and the data were consistent with pseudo second order kinetic kinetics. According to result of thermodynamic study, entropy changes $\left(\triangle S^{\circ}\right)$, enthalpy changes $\left(\Delta \mathrm{H}^{\circ}\right)$ and Gibbs free energy $\left(\Delta \mathrm{G}^{\circ}\right)$ were negative that represent the adsorption process is spontaneous and exothermic. Conclusion: The results of this study showed that the process of adsorption of MIP is a very effective process for removing the CIP from aqueous solutions.

Key words: Ciprofloxacin, Molecularly imprinted polymer, Thermodynamics, Kinetics, Aqueous solution.

Correspondence

Prof. Ferdos Kord Mostafapour,

Department of Environmental Health Engineering, Health Promotion Research Center, Zahedan University of Medical Sciences, Zahedan, IRAN.

Email id: ferdoskord@gmail.com

DOI: 10.5530/ijpi.2021.3.47

\section{INTRODUCTION}

Pharmaceutical products and effluents have been identified as potential contaminants in water resources, which is a concern as emerging contaminants. ${ }^{1}$ In recent years, people's access to and consumption of drugs has increased due to the advancement of medical sciences and pharmacy. Iran is one of the largest drug users in the world, so that it is among the top 20 countries in the world in terms of drug consumption and in Asia, after China, it ranks second in drug consumption. ${ }^{2}$ Drugs are known as environmental pollution and are classified as compounds with biological accumulation and are considered as hazardous chemicals. ${ }^{3}$ Among all the drugs that cause environmental pollution, antibiotics have an important place due to their high consumption in medicine and veterinary medicine. ${ }^{4}$ Antibiotics are widely used to treat many infectious diseases and fungi and are considered as contaminants of water and sewage. ${ }^{5}$ Improper use of antibiotics and their discharge into the environment have serious and dangerous consequences. About 30-90\% of antibiotics are not metabolized in the body $y^{6}$ and enter the environment through urine and feces, so the main source of antibiotics in the environment is wastewater treatment effluent. ${ }^{7}$ These compounds are not completely removed through wastewater treatment plant effluents and pollute water sources. ${ }^{8}$ Characteristics of antibiotics include low biodegradability, high toxicity, carcinogenicity and mutagenicity. ${ }^{9}$
CIP is an antibiotic from the group of Fluoroquinolones used to treat bacterial infections. The presence of this antibiotic is dangerous even in low concentrations and leads to increased antibiotic resistance, effect on non-target pathogens, alteration of the structure of aquatic algae, interference with plant photosynthesis and apparent abnormalities in plants. ${ }^{10}$ Therefore, the removal of antibiotics before entering the aquatic environment and also the reuse of water is necessary, ${ }^{11}$ which due to their high polarity and resistant nature, which is a significant threat to human health. ${ }^{12}$ Methods used for removal include: chemical oxidation, membrane processes, bioremediation, ozonation and adsorption techniques. ${ }^{13}$ Elimination or reduction of antibiotics through bioremediation is difficult due to the presence of a stable naphthol ring (as the main structure) and its toxicity to microorganisms as well as its low biodegradability. ${ }^{14}$ Membrane processes are also often hampered by the membrane's high vulnerability to organic solvents in wastewater containing antibiotics, thus reducing their efficiency. ${ }^{15}$ Adsorption process compared to other treatment techniques in terms of initial cost, simplicity and flexibility in design, easy operation and insensitivity to pollutants and toxic compounds, production of high quality effluent, no free radicals and hazardous substances as one of it is the most valuable and effective method of removing various pollutants in water and wastewater. ${ }^{16,17}$ 
MIP are synthetic polymeric materials with complementary mold sites for a particular molecule and the high dependence of the samples on a similar molecular structure ${ }^{18}$ that have properties similar to natural receptors. ${ }^{19}$ MIP have pre-defined holes for the identification of target samples and synthetic receptors capable of fabricating advanced analytical devices. ${ }^{20}$ These materials are able to detect a specific molecule or a family of compounds in a simple and fast way ${ }^{21}$ and in recent years have been widely used in many areas such as sensors, catalysts, solid phase extraction, etc. ${ }^{22}$ and to The mass copolymerization device is prepared from the monomer and cross-linked in the presence of the mold molecule. ${ }^{22,23}$ Therefore, the aim of this study was to investigate the isotherm, synthesis and thermodynamics of CIP adsorption by MIP form from aqueous solutions.

\section{MATERIALS AND METHODS}

This is an experimental-laboratory study that has been done in Zahedan University of Medical Sciences. In this study, iron chloride $\left(\mathrm{FeCl}_{3}\right)$, pyrrole and CIP were used as templates for a MIP purchased from Sigma Aldrich Co. To make stock solutions at a concentration of $500 \mathrm{mg} / \mathrm{L}$ for antibiotics, pour $0.5 \mathrm{~g}$ of CIP separately into a $1000 \mathrm{mg} / \mathrm{L}$ flask and add distilled water to the specified level and place on a magnetic stirrer. After complete dissolution of the antibiotic, the solution was made to volume. Stocks were stored in sealed containers and refrigerated and made weekly.

For MIP synthesis, $0.3 \mathrm{~g}$ of CIP powder was weighed and mixed with $100 \mathrm{ml}$ of distilled water in a $250 \mathrm{ml}$ beaker. (A watch glass was placed on the human mouth.) The mixture was placed under the hood and on a magnetic stirrer until CIP was completely dissolved in water. After about an hour, the solution was removed from the magnetic stirrer, and then the solution was placed in a dark place for 48 to $72 \mathrm{hr}$ for polymerization. After preparing the polymer, it was first rinsed with a vacuum filter and then placed in a Soxhlet machine for approximately $8 \mathrm{hr}$ to completely separate the imprinted molecular (CIP) from the polymer. Finally, the polymer was dried in an oven at $100^{\circ} \mathrm{C}$. It was left for $1.5-2 \mathrm{hr}$. Finally, the dried polymer was pulverized using a porcelain mortar. Simultaneously with the molecular mold polymer, as a reference, a non-molded polymer (NIP) was prepared simultaneously in the same molecular mold polymer method but without adding a pattern to be able to adsorb it into the molecule. Compare the target with the MIP. Finally, the polymer was placed in the oven for drying at a temperature of $100^{\circ} \mathrm{C}$ for $1.5-2 \mathrm{hr}$. Finally, the dried polymer was powdered using a Chinese mortar. Simultaneously with the MIP, as a reference, a non-imprinted polymer (NIP) was prepared simultaneously in the same MIP method but without adding a pattern to compare its adsorption capacity in the target molecular with MIP.

The experiments were performed optimally. In this study, by setting the desired parameter and setting other parameters, the process was performed and after determining the relevant efficiencies, the optimal value of the desired variable was determined, then the optimal value obtained was placed in the next step. Optimization by MIP and NIP was performed simultaneously at all stages. For example, to determine the effect of $\mathrm{pH}$, experiments were performed at $\mathrm{pH}$ of 3-11. To adjust the $\mathrm{pH}, 0.1 \mathrm{~N}$ hydrochloric acid and sodium hydroxide were used. At this stage by keeping the polymer dose variables constant, initial antibiotic concentration, contact time and temperature; the effect of $\mathrm{pH}$ on the elimination of CIP antibiotics was investigated. A constant concentration of $25 \mathrm{mg} / \mathrm{L}$ was prepared from stock solution for CIP. After optimizing the $\mathrm{pH}$, the other parameters were also optimized and the removal observation and the amount of adsorption were calculated through the following equations: $:^{24,25}$

$$
\begin{aligned}
& \% \mathrm{R}=\left(\frac{\mathrm{C}_{0}-\mathrm{Ce}}{\mathrm{C}_{0}}\right) \times 100 \\
& \mathrm{q}_{\mathrm{e}}=\left(\frac{\mathrm{C}_{0}-\mathrm{C}_{\mathrm{e}}}{\mathrm{M}}\right) \mathrm{V}
\end{aligned}
$$

In the above equations, $\mathrm{C}_{0}$ and $\mathrm{C}_{\mathrm{e}}$ are the initial and equilibrium concentrations of CIP after adsorption, $\mathrm{q}_{\mathrm{e}} \mathrm{mg}$ of CIP adsorbed on the adsorbent, $\mathrm{M}$ and $\mathrm{V}$ are the adsorbent mass $(\mathrm{g})$ and solution volume (L), respectively.

Adsorption kinetics: The pseudo-first-order kinetics equation is based on the adsorbent capacity and is used when adsorption occurs by the diffusion mechanism inside a boundary layer. The pseudo-second-order kinetics equation indicates the chemical adsorption of the dominant and controlling mechanism in the adsorption process and according to the solid phase adsorption states that chemical adsorption is the slowing step of the adsorption process (6).

Equation 3: pseudo-first-order kinetic model. ${ }^{26}$

$$
\log \left(q_{e}-q_{t}\right)=\log q_{e}-t
$$

$\mathrm{q}_{\mathrm{e}}$ and $\mathrm{q}_{\mathrm{t}}$ represent the adsorption capacity at equilibrium time and at time $(\mathrm{mg} / \mathrm{g}) \mathrm{t}$ and $\mathrm{k}_{1}$, respectively, reaction rate coefficients are $\left(\mathrm{min}^{-1}\right)$. The values of $q_{e}$ and $k_{1}$ are the width of the origin and the slope of the linear graph $\ln \left(\mathrm{q}_{\mathrm{e}}-\mathrm{q}_{\mathrm{t}}\right)$ versus $\mathrm{t}$, respectively.

Equation 4: pseudo-second-order kinetic model. ${ }^{27}$

$$
\frac{1}{\mathrm{q}_{\mathrm{t}}}=\frac{1}{\mathrm{~K}_{2} \mathrm{q}_{\mathrm{e}}^{2}}+\frac{\mathrm{t}}{\mathrm{q}_{\mathrm{e}}}
$$

$\mathrm{K}_{2}$ is a pseudo-second-order reaction constant in terms of ( $\mathrm{mg} / \mathrm{g}$. $\mathrm{min}$ ). The values of $\mathrm{q}_{e}$ and $\mathrm{k}_{2}$ are determined by the slope and width from the linear origin $t / q_{t}$ versus $t$, respectively (6).

Adsorption isotherms: In this study, Langmuir and Freundlich isotherm models were used to analyze the experimental data and describe the equilibrium state in the adsorption between solid and liquid phases. The Langmuir isotherm model shows the homogeneous adsorption of a layer of adsorbent with the same energy on all adsorbent surfaces, and also states that all adsorption sites have the same coherence with the adsorbent molecules and no transfer process from the adsorbent occurs at the adsorbent surface. ${ }^{28}$ While Freundlich isotherm is based on multilayer and heterogeneous adsorption of adsorbent on adsorbent. ${ }^{29}$

Equation 5: Langmuir model: ${ }^{30}$

$$
\frac{\mathrm{C}_{\mathrm{e}}}{\mathrm{q}_{\mathrm{e}}}=\frac{1}{\mathrm{q}_{\mathrm{m}} \mathrm{K}_{1}}+\frac{\mathrm{C}_{\mathrm{e}}}{\mathrm{q}_{\mathrm{m}}}
$$

In this equation $(\mathrm{mg} / \mathrm{L}) \mathrm{C}_{e}$ is the equilibrium concentration of $\mathrm{CIP}$, $(\mathrm{mg} / \mathrm{g}) \mathrm{q}_{\mathrm{e}}$ is the amount of CIP adsorbed at equilibrium, $\mathrm{q}_{\mathrm{m}}(\mathrm{mg} / \mathrm{g})$ is the maximum adsorption capacity and $(\mathrm{L} / \mathrm{mg}) \mathrm{k}_{\mathrm{l}}$ is Langmuir constant.

The type of adsorption desirability of the adsorption process in the Langmuir model is determined by the $\mathrm{R}_{\mathrm{L}}$ factor (Equation 6).

$$
\mathrm{R}_{\mathrm{L}}=\frac{1}{1+\mathrm{K}_{1} \mathrm{C}_{0}}
$$

If $\mathrm{R}_{\mathrm{L}}>1$ indicates undesirable adsorption, if $\mathrm{R}_{\mathrm{L}}=1$ linear adsorption, and if $\mathrm{R}_{\mathrm{L}}=0$ irreversible adsorption and $1<\mathrm{R}_{\mathrm{L}}<0$ indicates optimal adsorption. ${ }^{30}$ Equation 7: Freundlich model: ${ }^{31}$

$$
\log q_{e}=\log C e+\log K_{F}
$$

In the Freundlich model equation, the $\mathrm{K}_{\mathrm{F}}\left(\mathrm{mg} / \mathrm{g}\left(\mathrm{L} / \mathrm{mg}^{1 / \mathrm{n}}\right)\right.$ and $\mathrm{n}$ parameters of the Freundlich constants depend on the adsorption capacity and 
intensity, if the value $\mathrm{n}<1$, it indicates poor adsorption, the value of $\mathrm{n}$ between 1-2 indicates the average adsorption and the value $n=2-10$ indicates the desired adsorption. The parameters $\mathrm{n}$ and $\mathrm{K}_{\mathrm{L}}$ are determined by the slope and width from the origin of the linear graph $\mathrm{Ln} \mathrm{q}_{e}$ versus Ln $\mathrm{C}_{\mathrm{e}}$, respectively.

Adsorption thermodynamics: In studying the adsorption process, three thermodynamic parameters should be examined and their values determined. These parameters are: ${ }^{32}$

1. Standard Free Energy $\left(\Delta \mathrm{G}^{\circ}\right)$

2. Standard enthalpy $\left(\Delta \mathrm{H}^{\circ}\right)$

3. Standard entropy $\left(\Delta \mathrm{S}^{\circ}\right)$

The values of $\Delta \mathrm{H}^{\circ}$ and $\Delta \mathrm{S}^{\circ}$ are obtained from the following equations:

$$
\begin{gathered}
\operatorname{Ln} K_{0}=\left(\Delta S^{0} / R\right)-\left(\Delta H^{0} / R T\right) \\
K_{0}=q_{e} / C_{e}
\end{gathered}
$$

In the above equations, $\mathrm{R}$ represents the global constant of gases $(8 / 31$ $\mathrm{J} / \mathrm{mol}$. k), $\mathrm{T}$ is the temperature of the solution in terms of $\mathrm{T}(\mathrm{K})$ and $\mathrm{K}_{0}$ $(\mathrm{L} / \mathrm{g})$, the ratio of the amount of CIP adsorbed on the adsorbent $(\mathrm{mg} / \mathrm{g})$ to the amount remaining in the solution $(\mathrm{mg} / \mathrm{L}) . \Delta \mathrm{H}^{\circ}$ and $\Delta \mathrm{S}^{\circ}$ are also calculated from the origin of the linear graph $\mathrm{Ln} \mathrm{k}_{0}$ versus $1 / \mathrm{T}$, respectively, through the slope and width. The value of $\Delta G^{\circ}$ is also obtained from Equation $10 . .^{33}$

$$
\Delta G^{0}=-R T \operatorname{Ln} K_{0}
$$

\section{RESULTS}

Examination of Figure 1, shows that by increasing the $\mathrm{pH}$ from 3 to 7 , the removal efficiency decreases from $85.4 \%$ to $92.4 \%$, and at $\mathrm{pH}$ equal to 9 , the removal efficiency decreases to $88.7 \%$ and polymers destroyed at a $\mathrm{pH}$ equal to 11 . When destroyed, the solution becomes colored and cloudy. As shown in Figure 2, with increasing initial concentration from 5 to $75 \mathrm{mg} / \mathrm{L}$, the removal efficiency decreases from 73.6 to $96.25 \%$, while with increasing initial concentration more than $75 \mathrm{mg} / \mathrm{L}$, the removal efficiency decreases. The results of this study, which show in Figure 3, the maximum removal efficiency at $60 \mathrm{~min}$ of contact time is $99.3 \%$. By increasing the MIP dose to $0.06 \mathrm{~g}$, the removal efficiency increases due to the constant concentration of CIP in the solution. Increasing the amount of MIP helped to improve the removal process of CIP (Figure 4). The results obtained from the isotherm and kinetics and thermodynamics of the adjustment data are shown in Tables 1,2 and 3, respectively.

\section{DISCUSSION}

The pKa levels of CIP are between 6.1 (for the carboxylic acid group) and 8.7 (for the amine group). ${ }^{34}$ The effect of $\mathrm{pH}$ change on CIP molecule showed that at $\mathrm{pH}$ less than 6.1 times the surface antibiotic CIP appears cationic and positive due to protonation of amine groups. At $\mathrm{pH}$ above 8.7, the CIP molecule converts to the anionic form due to the loss of protons from the carboxylic group in the antibiotic structure. In the range of $\mathrm{pH}=6.8-7.1$, due to the deprotonation of the carboxyl group, it leads to the production of negatively charged carboxylates. However, the amine group remains protonated and positively charged. ${ }^{35}$ Therefore, in this $\mathrm{pH}$ range, most of the CIP molecule in aqueous solution is uncharged, in other words, it has a positive and a negative part. The formation of the CIP molecule at a $\mathrm{pH}$ between 6.7-7.1 has also been confirmed in other studies, ${ }^{15,36}$ since the $\mathrm{pK}_{\mathrm{a}}$ of methacrylic acid in the polymer is reported to be about 4.65 , the $\mathrm{COOH}$ functional groups of methacrylic acid in acidic media ( $\mathrm{pH} 4.65$ is converted to $\mathrm{COOH}^{2+}$ which has a positive charge. ${ }^{37}$ Therefore, in acidic and somewhat neutral solutions ( $\mathrm{pH}=6.1-6.8)$, the conditions for the interaction and adsorption mechanism between CIP and polymer particles are suitable. ${ }^{38}$

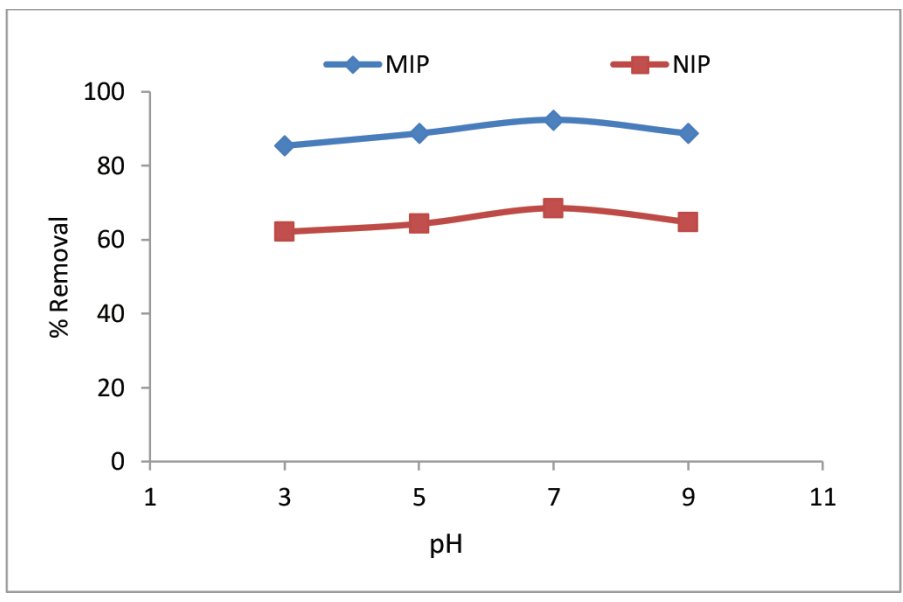

Figure 1: Effect of different $\mathrm{pH}$ on the removal of CIP antibiotic by MIP (CIP concentration: $25 \mathrm{mg} / \mathrm{L}$, MIP dosage: $0.4 \mathrm{~g} / \mathrm{L}$, contact time: $60 \mathrm{~min}$ and tem; $25^{\circ} \mathrm{C}$.

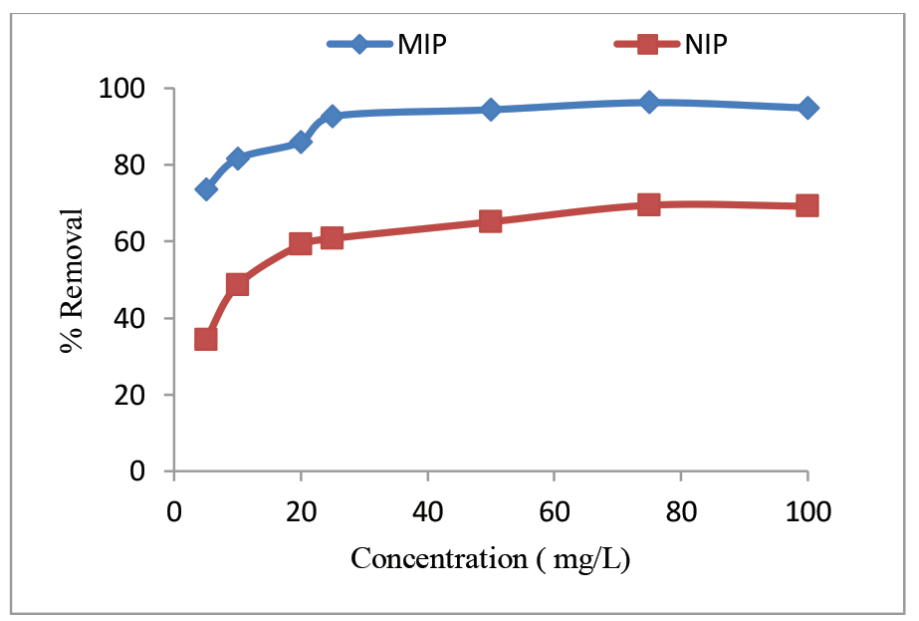

Figure 2: Effect of CIP concentration on the removal of CIP antibiotic by MIP (pH: 7, MIP dosage: $0.4 \mathrm{~g} / \mathrm{L}$, contact time: $60 \mathrm{~min}$ and tem; $25^{\circ} \mathrm{C}$.

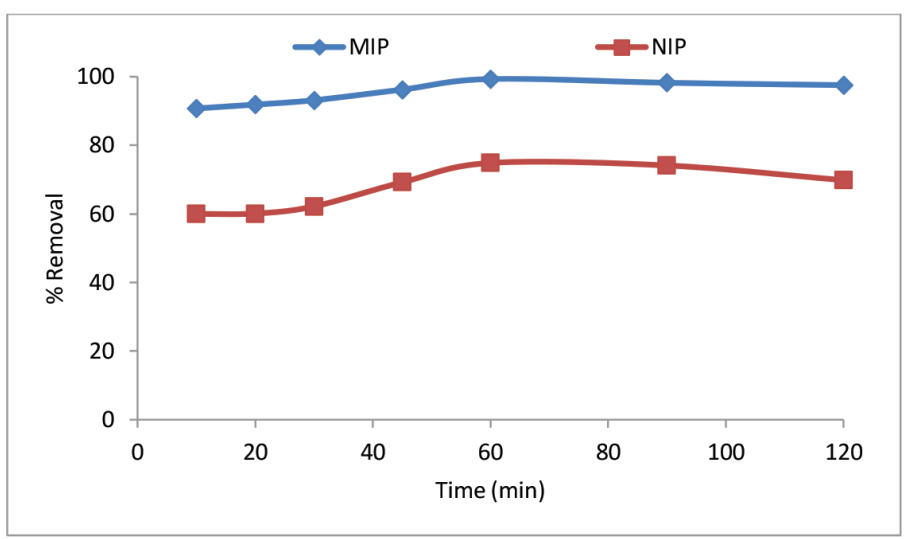

Figure 3: Effect of contact time on the removal of CIP antibiotic by MIP (CIP concentration: $25 \mathrm{mg} / \mathrm{L}$, MIP dosage: $0.4 \mathrm{~g} / \mathrm{L}, \mathrm{pH}: 7$ and tem; $25^{\circ} \mathrm{C}$. 


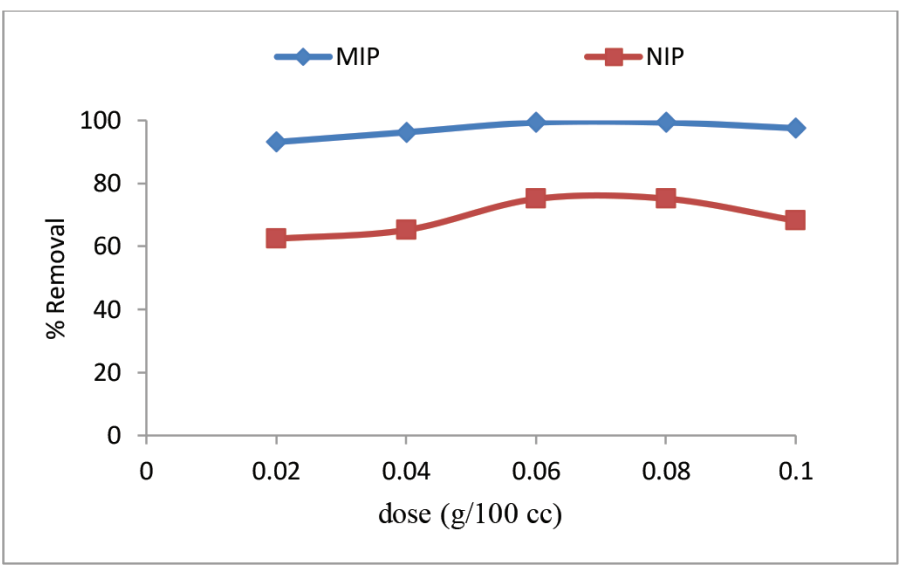

Figure 4: Effect of MIP dose on the removal of CIP antibiotic by MIP (CIP concentration: $25 \mathrm{mg} / \mathrm{L}$, time: $60 \mathrm{~min}, \mathrm{pH}: 7$ and tem; $25^{\circ} \mathrm{C}$.

With increasing the initial concentration of CIP, the removal efficiency decreases, because in a constant dose of adsorbent, the active sites of adsorption are constant, but with increasing the concentration of the contaminant, the number of mole contaminants in the reaction medium increases and therefore the removal efficiency decreases. ${ }^{39}$

With increasing the duration of contact time of the contaminant with the adsorbent of the MIP in solution, the removal efficiency increases to some extent and with further increase of the contact time no significant effect on the removal efficiency is observed and CIP molecules appear to saturate the surface. ${ }^{40}$

The adsorbent dose is one of the important factors in the rate of removal of contaminants by adsorption method, which if it is less than the required amount, the adsorption step may not be performed completely and the whole sample of adsorbent adsorption may not be. In this study, the MIP was considered as an adsorbent for CIP removal. ${ }^{41}$

The results obtained from the adsorption parameters of ciprofloxacin in Table 1 show that the value of $\mathrm{n}$ in the Freundlich model is less than 1 , which indicates poor adsorption. In the Langmuir model, the dimensionless coefficient of separation factor $\left(R_{L}\right)$ is between one and zero, which indicates the optimal adsorption. Therefore, adsorption of CIP on MIP adsorbent follows the Langmuir model with high regression coefficient.

According to the values obtained from the adsorption synthetic models shown in Table 2 , they show that the computational adsorption capacity $\left(\mathrm{q}_{\mathrm{e}}, \mathrm{cal}\right)$ obtained from the pseudo-second-order models compared to the pseudo-first-order kinetics, to the experimental adsorption capacity $\left(\mathrm{q}_{\mathrm{e}}\right.$, exp) are closer, so the predominant mechanism of the ciprofloxacin adsorption process by MIP is chemical adsorption.

The negative values of the standard $\Delta \mathrm{H}^{\circ}$ parameter or enthalpy given in Table 3 indicate the exothermic process of ciprofloxacin CIP adsorption by MIP and the possibility of physical adsorption. ${ }^{42}$ Negative values obtained for the $\Delta S^{\circ}$ parameter indicate that the removal efficiency, or in other words the degree of irregularity, decreases with increasing temperature during the adsorption process in the solid-liquid interface. ${ }^{43}$ This can be due to the reduction of the release of the contaminant on the adsorbent surface. Negative values of $\Delta G^{\circ}$ indicate that the process of CIP adsorption by MIP is endothermic and occurs spontaneously. Decreasing the values of $\Delta \mathrm{G}^{\circ}$ with increasing temperature indicates that the adsorption process is not desirable at higher temperatures. ${ }^{44}$
Table 1: Parameters of equilibrium isotherms of CIP adsorption on MIP.

\begin{tabular}{cc}
\hline Freundlich & Langmuir \\
\hline $\mathrm{R}^{2}=0.941$ & $\mathrm{R}^{2}=0.999$ \\
$\mathrm{n}=0.043$ & $\mathrm{R}_{\mathrm{L}}=0.0017$ \\
$\mathrm{~K}_{\mathrm{F}}=124 / 7$ & $\mathrm{~K}_{\mathrm{d}}=7 / 41$ \\
& $\mathrm{Q}_{\mathrm{m}}=112.3$ \\
\hline
\end{tabular}

Table 2: Kinetic parameters of CIP adsorption process on MIP.

\begin{tabular}{cc} 
pseudo-second-order & pseudo-first-order \\
\hline $\mathrm{R}^{2}=0.999$ & $\mathrm{R}^{2}=0.952$ \\
$\mathrm{~K}_{2}=0.007$ & $\mathrm{~K}_{\mathrm{l}}=0.046$ \\
$\mathrm{q}_{\mathrm{e}} \cdot \mathrm{cal}=123.4$ & $\mathrm{q}_{\mathrm{e}} \cdot \mathrm{cal}=14.46$ \\
\hline
\end{tabular}

Table 3: Values of thermodynamic parameters of CIP adsorption process on MIP.

\begin{tabular}{ccc}
\hline$\Delta \mathrm{S}^{\circ}(\mathrm{KJ} / \mathrm{mol})$ & $\Delta \mathrm{H}^{\circ}(\mathrm{KJ} / \mathrm{mol})$ & $\Delta \mathrm{G}^{\circ}(\mathrm{KJ} / \mathrm{mol})$ \\
\hline & & $20^{\circ} \mathrm{C}=-7.47$ \\
-0.00033 & -9.27 & $30^{\circ} \mathrm{C}=-11.41$ \\
& $40^{\circ} \mathrm{C}=-9.77$ \\
& $50^{\circ} \mathrm{C}=-7.88$ \\
\hline
\end{tabular}

\section{CONCLUSION}

In this study, the removal efficiency of CIP antibiotics by MIP was measured under optimal conditions with a value of $99.3 \%$. The results of isothermal and kinetic studies showed that the equilibrium data follow the Langmuir isotherm and the pseudo-second-order reaction kinetics. Negative $\Delta \mathrm{G}^{\circ}$ and $\Delta \mathrm{H}^{\circ}$ results indicated that ciprofloxacin adsorption was exothermic and spontaneously. Decreasing the values of $\Delta \mathrm{G}^{\circ}$ with increasing temperature indicates that the adsorption process is not desirable at higher temperatures. Therefore, the results show that the MIP is an adsorbent with a very high and economically suitable ability to remove various contaminants from aqueous solutions.

\section{ACKNOWLEDGEMENT}

The authors are grateful from Zahedan University of Medical Sciences because of supporting of this research (Code: 1399-9637).

\section{CONFLICT OF INTEREST}

The authors declare no conflict of interest.

\section{ABBREVIATIONS}

MIP: Molecularly imprinted polymer; CIP: Ciprofloxacin.

\section{REFERENCES}

1. Balarak D, Baniasadi M, Bazzi M. Adsorption equilibrium and thermodynamic studies of ciprofloxacin from aqueous solutions by magnetic bentonite nanocomposites. Int J Pharm Investig. 2020;10(3):339-43. doi: 10.5530/ ijpi.2020.3.60.

2. Mahvi AH, Mostafapour FK. Biosorption of tetracycline from aqueous solution by azolla filic uloides: equilibrium kinetic and thermodynamics studies. Fresenius Environ Bull. 2018;27(8):5759-67.

3. Zhang Z, Li H, Liu H. Insight into the adsorption of tetracycline onto amino and amino-Fe3+ gunctionalized mesoporous silica: effect of functionalized groups. J Environ Sci (China). 2018;65:171-8. doi: 10.1016/j.jes.2016.10.020, PMID 29548388. 
4. Lv JM, Ma YL, Chang X, Fan SB. Removal and removing mechanism of tetracycline residue from aqueous solution by using $\mathrm{Cu}-13 \mathrm{X}$. Chem Eng J. 2015;273:247-53. doi: 10.1016/j.cej.2015.03.080.

5. Rostamian R, Behnejad H. A comparative adsorption study of sulfamethoxazole onto graphene and graphene oxide nanosheets through equilibrium, kinetic and thermodynamic modeling. Process Saf Environ Prot. 2016:102:20-9. doi: 10.1016/j.psep.2015.12.011.

6. Chen $\mathrm{H}, \mathrm{Gao}$ B, Li H. Removal of sulfamethoxazole and ciprofloxacin from aqueous solutions by graphene oxide. J Hazard Mater. 2015;282:201-7. doi: 10.1016/j.jhazmat.2014.03.063, PMID 24755346.

7. Peng $\mathrm{X}, \mathrm{Hu}$ F, Dai H, Xiong Q. Study of adsorption mechanism of ciprofloxacin antibiotics onto graphitic ordered mesoporous carbons. J Taiwan Inst Chem Eng. 2016;8:1-10.

8. Parsa JB, Panah TM, Chianeh FN. Removal of ciprofloxacin from aqueous solution by continuous flow electro-coagulation process. Korean J Chem Eng 2016;33(3):893-901. doi: 10.1007/s11814-015-0196-6.

9. Ahmadi S, Banach A. Kord Mostafapour F. Study survey of cupric oxide nanoparticles in removal efficiency of ciprofloxacin antibiotic from aqueous solution: adsorption isotherm study. Desalin Water Treat. 2017;89:297-303.

10. Ding R, Zhang P, Seredych M, Bandosz TJ. Removal of antibiotics from water using sewage sludge and waste oil sludge-derived adsorbents. Water Res. 2012;46(13):4081-90. doi: 10.1016/j.watres.2012.05.013, PMID 22673337.

11. Cao J, Xiong Z, Lai B. Effect of initial $\mathrm{pH}$ on the tetracycline (TC) removal by zerovalent iron: adsorption, oxidation and reduction. Chem Eng J. 2018;343:492-9. doi: 10.1016/j.cej.2018.03.036

12. Acosta R, Fierro V, Martinez de Yuso AM, Nabarlatz D, Celzard A. Tetracycline adsorption onto activated carbons produced by $\mathrm{KOH}$ activation of tyre pyrolysis char. Chemosphere. 2016;149:168-76. doi: 10.1016/j.chemosphere.2016.01.093, PMID 26855221.

13. Martins AC, Pezoti O, Cazetta AL, Bedin KC, Yamazaki DAS, Bandoch GFG, et al. Removal of tetracycline by $\mathrm{NaOH}$-activated carbon produced from macadamia nut shells: kinetic and equilibrium studies. Chem Eng J. 2015;260:291-9. doi: 10.1016/j.cej.2014.09.017.

14. Peterson JW, Petrasky LJ, Seymour MD, Burkhart RS, Schuiling AB. Adsorption and breakdown of penicillin antibiotic in the presence of titanium oxide nanoparticles in water. Chemosphere. 2012;87(8):911-17. doi: 10.1016/j.chemosphere.2012.01.044, PMID 22342282.

15. Darweesh TM, Ahmed MJ. Adsorption of ciprofloxacin and norfloxacin from aqueous solution onto granular activated carbon in fixed bed column. Ecotoxicol Environ Saf. 2017;138:139-45. doi: 10.1016/j.ecoenv.2016.12.032, PMID 28040619.

16. Balarak $D$, Khatibi $A D$, Chandrika $K$. Antibiotics removal from aqueous solution and pharmaceutical wastewater by adsorption process: a review. Int J Pharm Investig. 2020;10(2):106-11. doi: 10.5530/ijpi.2020.2.19.

17. Kerkez-Kuyumcu Ö, Bayazit SS, Salam MA. Antibiotic amoxicillin removal from aqueous solution using magnetically modified graphene nanoplatelets. J Ind Eng Chem. 2016;36:198-205. doi: 10.1016/j.jiec.2016.01.040.

18. Mostafapour FK, Haseeb S, Balarak D, Moein H, Sajadi AA, Jalalzaei Z. Thermodynamic study of amoxicillin and naphthalene adsorption on activated carbon derived from Salvadora persica. Int J Pharm Investig. 2021:11(1):41-5. doi: 10.5530/ijpi.2021.1.8.

19. Lu W, Liu J, Li J, Wang X, Lv M, Cui R, Chen L. Dual-template molecularly imprinted polymers for dispersive solid-phase extraction of fluoroquinolones in water samples coupled with high performance liquid chromatography. Analyst. 2019;144(4):1292-302. doi: 10.1039/c8an02133c, PMID 30548030

20. Sun X, Wang J, Li Y, Yang J, Jin J, Shah SM, Chen J. Novel dummy molecularly imprinted polymers for matrix solid-phase dispersion extraction of eight fluoroquinolones from fish samples. J Chromatogr A. 2014;1359:1-7. doi: 10.1016/j. chroma.2014.07.007, PMID 25085823.

21. Cacho C, Turiel E, Pérez-Conde C. Molecularly imprinted polymers: an analytical tool for the determination of benzimidazole compounds in water samples. Talanta. 2009;78(3):1029-35. doi: 10.1016/j.talanta.2009.01.007, PMID 19269468.

22. Pupin RR, Foguel MV, Gonçalves LM, Sotomayor MdPT. Magnetic molecularly imprinted polymers obtained by photopolymerization for selective recognition of penicillin G. J Appl Polym Sci. 2020;137(13):1-10. doi: 10.1002/app.48496.

23. Meng Z, Chen W, Mulchandani A. Removal of estrogenic pollutants from contaminated water using molecularly imprinted polymers. Environ Sci Technol. 2005;39(22):8958-62. doi: 10.1021/es0505292, PMID 16323800

24. Li M, Liu Y, Liu S, Shu D, Zeng G, Hu X, Tan X, Jiang L, Yan Z, Cai X. $\mathrm{Cu}(\mathrm{II})$-influenced adsorption of ciprofloxacin from aqueous solutions by magnetic graphene oxide/nitrilotriacetic acid nanocomposite: competition and enhancement mechanisms. Chem Eng J. 2017;319:219-28. doi: 10.1016/j.cej.2017.03.016.

25. Peng $H$, Pan B, Wu M, Liu Y, Zhang D, Xing B. Adsorption of ofloxacin and norfloxacin on carbon nanotubes: hydrophobicity- and structure-controlled process. J Hazard Mater. 2012;233-234:89-96. doi: 10.1016/j.jhazmat.2012.06.058, PMID 22819959.

26. Lin Y, Xu S, Li J. Fast and highly efficient tetracyclines removal from environmental waters by graphene oxide functionalized magnetic particles. Chem Eng J. 2013;225:679-85. doi: 10.1016/j.cej.2013.03.104.

27. Li G, Zhang D, Wang M, Huang J, Huang L. Preparation of activated carbons from Iris tectorum employing ferric nitrate as dopant for removal of tetracycline from aqueous solutions. Ecotoxicol Environ Saf. 2013;98:273-82. doi: 10.1016/j. ecoenv.2013.08.015, PMID 24021870.

28. Balarak D, Ganji F, Chandrika K, Haseeb S. Montmorillonite nanoparticles effectiveness in removal of amoxicillin from water solutions. Int J Pharm Investig. 2021;10(2):122-6.

29. Gao Y, LiY, Zhang L, Huang H, Hu J, Shah SM, Su X. Adsorption and removal of tetracycline antibiotics from aqueous solution by graphene oxide. J Colloid Interface Sci. 2012;368(1):540-6. doi: 10.1016/j.jcis.2011.11.015, PMID 22138269.

30. Ji L, Chen W, Duan L, Zhu D. Mechanisms for strong adsorption of tetracycline to carbon nanotubes: a comparative study using activated carbon and graphite as adsorbents. Environ SciTechnol. 2009:43(7):2322-7. doi: 10.1021/es803268b, PMID 19452881.

31. Marzbali MH, Esmaieli M, Abolghasemi H, Marzbali MH. Tetracycline adsorption by H3PO4-activated carbon produced from apricot nut shells: A batch study. Process Saf Environ Prot. 2016;102:700-9. doi: 10.1016/j.psep.2016.05.025.

32. Balarak D, Chandrika K. Batch Studies on biosorption of ciprofloxacin on Freshwater Macro alga Lemna minor. Int J Pharm Investig. 2019;9(3):117-21. doi: 10.5530/ijpi.2019.3.22.

33. Ahmed MB, Zhou JL, Ngo HH, Guo W. Adsorptive removal of antibiotics from water and wastewater: progress and challenges. Sci Total Environ. 2015;532:112-26. doi: 10.1016/j.scitotenv.2015.05.130, PMID 26057999.

34. Zhang Y, Jiao Z, Hu Y, Lv S, Fan H, Zeng Y, Hu J, Wang M. Removal of tetracycline and oxytetracycline from water by magnetic Fe304@graphene. Environ Sci Pollut Res Int. 2017;24(3):2987-95. doi: 10.1007/s11356-016-7964-7. PMID 27848131.

35. Ren $X$, Chen $C$, Nagatsu M, Wang $X$. Carbon nanotubes as adsorbents in environmental pollution management: a review. Chem Eng J. 2011;170(2-3):395-410. doi: 10.1016/j.cej.2010.08.045

36. Ji L, Shao Y, Xu Z, Zheng S, Zhu D. Adsorption of monoaromatic compounds and pharmaceutical antibiotics on carbon nanotubes activated by $\mathrm{KOH}$ etching. Environ Sci Technol. 2010;44(16):6429-36. doi: 10.1021/es1014828, PMID 20704245.

37. Moein H, Balarak D, Meshkinain A, Chandrika K, Yazdani N. Effects of operational parameters on the removal of tetracycline from aqueous solutions by electrocoagulation. Int J Pharm Investig. 2021;11(1):23-6. doi: 10.5530/ijpi.2021.1.5.

38. Li S, Zhang $X$, Huang $Y$. Zeolitic imidazolate framework-8 derived nanoporous carbon as an effective and recyclable adsorbent for removal of ciprofloxacin antibiotics from water. J Hazard Mater. 2017;321:711-19. doi: 10.1016/j. jhazmat.2016.09.065, PMID 27701060.

39. Wang F, Yang B, Wang H, Song Q, Tan F, Cao Y. Removal of ciprofloxacin from aqueous solution by a magnetic chitosan grafted graphene oxide composite. $J$ Mol Liq. 2016;222:188-94. doi: 10.1016/j.molliq.2016.07.037.

40. 40. Zha Sx, Zhou Y, Jin X, Chen Z. The removal of amoxicillin from wastewater using organobentonite. J Environ Manage. 2013;129:569-76. doi: 10.1016/j.jenvman.2013.08.032, PMID 24029460.

41. Guler UA, Sarioglu M. Removal of tetracycline from wastewater using pumice stone: equilibrium, kinetic and thermodynamic studies. J Environ Health Sci Eng. 2014;12:79. doi: 10.1186/2052-336X-12-79, PMID 24936305.

42. Azarpira $H$, Mahdavi $Y$, Khaleghi O. Thermodynamic studies on the removal of metronidazole antibiotic by multi-walled carbon nanotubes. Pharm Lett. 2016;8(11):107-13

43. Yu F, LiY, Han S, Ma J. Adsorptive removal of antibiotics from aqueous solution using carbon Materials. Chemosphere. 2016;153:365-85. doi: 10.1016/j.chemosphere.2016.03.083, PMID 27031800.

44. Rahardjo AK, Susanto MJ, Kurniawan A, Indraswati N, Ismadji S. Modified Ponorogo bentonite for the removal of ampicillin from wastewater. J Hazard Mater. 2011;190(1-3):1001-8. doi: 10.1016/j.jhazmat.2011.04.052, PMID 21550716.

Article History: Submission Date : 14-08-2021; Revised Date : 04-09-2021; Acceptance Date : 27-09-2021.

Cite this article: Mostafapour FK, Khatibi AD, Bazi M, Siddiqui SH, Balarak D. Investigation of Isotherm, Kinetics and Thermodynamics of Ciprofloxacin Adsorption by Molecularly Imprinted Polymer from Aqueous Solutions. Int. J. Pharm. Investigation. 2021;11(3):269-73. 